\title{
Impact of pH Management Interval on Biohydrogen Production from Organic Fraction of Municipal Solid Wastes by Mesophilic Thermophilic Anaerobic Codigestion
}

\author{
Chaudhry Arslan,, ${ }^{1,2}$ Asma Sattar, ${ }^{1}$ Ji Changying, ${ }^{1}$ Abdul Nasir, ${ }^{2}$ \\ Irshad Ali Mari, ${ }^{3}$ and Muhammad Zia Bakht ${ }^{4}$ \\ ${ }^{1}$ College of Engineering, Nanjing Agricultural University, Nanjing, Jiangsu 210031, China \\ ${ }^{2}$ Department of Structures and Environmental Engineering, University of Agriculture, Faisalabad 38000, Pakistan \\ ${ }^{3}$ Faculty of Agricultural Engineering, Sindh Agriculture University, Tandojam 70060, Pakistan \\ ${ }^{4}$ Institute of Food Science and Technology, University of Agriculture, Faisalabad 38000, Pakistan \\ Correspondence should be addressed to Ji Changying; chyji@njau.edu.cn
}

Received 27 August 2015; Revised 16 November 2015; Accepted 2 December 2015

Academic Editor: Wen-Jing Lu

Copyright (C) 2015 Chaudhry Arslan et al. This is an open access article distributed under the Creative Commons Attribution License, which permits unrestricted use, distribution, and reproduction in any medium, provided the original work is properly cited.

\begin{abstract}
The biohydrogen productions from the organic fraction of municipal solid wastes (OFMSW) were studied under pH management intervals of $12 \mathrm{~h}$ (PM12) and $24 \mathrm{~h}$ (PM24) for temperature of $37 \pm 0.1^{\circ} \mathrm{C}$ and $55 \pm 0.1^{\circ} \mathrm{C}$. The OFMSW or food waste (FW) along with its two components, noodle waste (NW) and rice waste (RW), was codigested with sludge to estimate the potential of biohydrogen production. The biohydrogen production was higher in all reactors under PM12 as compared to PM24. The drop in pH from 7 to 5.3 was observed to be appropriate for biohydrogen production via mesophilic codigestion of noodle waste with the highest biohydrogen yield of $145.93 \mathrm{~mL} / \mathrm{g} \mathrm{COD}_{\text {removed }}$ under $\mathrm{PM} 12$. When the temperature was increased from $37^{\circ} \mathrm{C}$ to $55^{\circ} \mathrm{C}$ and $\mathrm{pH}$ management interval was reduced from $24 \mathrm{~h}$ to $12 \mathrm{~h}$, the biohydrogen yields were also changed from $39.21 \mathrm{~mL} / \mathrm{g} \mathrm{COD}_{\text {removed }}$ to $89.67 \mathrm{~mL} / \mathrm{g} \mathrm{COD}_{\text {removed }}, 91.77 \mathrm{~mL} / \mathrm{g} \mathrm{COD}_{\text {removed }}$ to $145.93 \mathrm{~mL} / \mathrm{g} \mathrm{COD}_{\text {removed }}$, and $15.36 \mathrm{~mL} / \mathrm{g} \mathrm{COD}_{\text {removed }}$ to $117.62 \mathrm{~mL} / \mathrm{g} \mathrm{COD}_{\text {removed }}$ for FW, NW, and RW, respectively. The drop in pH and VFA production was better controlled under PM12 as compared to PM24. Overall, PM12 was found to be an effective mean for biohydrogen production through anaerobic digestion of food waste.
\end{abstract}

\section{Introduction}

Anaerobic digestion is in practice for more than a century and specifically from the last two decades, it has been used for biological hydrogen production [1]. Although a lot of research is done in this field, still hydrogen requirement is fulfilled by other conventional processes like thermal or electrochemical, which are expensive and also not environment-friendly $[2,3]$. On the other end, hydrogen produced by biological means, such as dark fermentation and photofermentation, is not enough to meet the demands, as the processes are not too efficient. Mostly, dark fermentation using mix consortia of Clostridium is preferred over photofermentation, which has an advantage of higher yield $[4,5]$. Apart from the yield, mix consortia of Clostridium that can survive better under a wide range of environmental conditions are used as hydrogen producers in dark fermentation [6]. Basically, Clostridium is Gram-positive and spore-forming anaerobic bacteria and mix consortia of Clostridium are easily available in the form of sludge, which makes it a suitable economical inoculum for hydrogen production [7]. Sludge also contains hydrogen consumers, that is, methanogens, that cannot survive at higher temperature, whereas Clostridium can survive by forming protective spores [8]. Keeping in view the spore forming property of Clostridium under high temperature, heat treatment in an oven is widely opted to deactivate methanogens due to easy operation and availability [9].

Along with inoculum, feed stock is also required to produce biohydrogen by anaerobic digestion. Though a variety of feedstock are tested for biohydrogen production, like 
TABLE 1: Properties of test materials.

\begin{tabular}{lccccc}
\hline Parameter & Unit & Sludge & Food waste & Rice waste & Noodles waste \\
\hline TS & $\%$ & 58.59 & 30.32 & 39.88 & 39.30 \\
VS & $\%$ & 2.87 & 26.9 & 79.65 & 28.51 \\
Glucose & $\mathrm{g} / \mathrm{L}$ & 2.49 & 65.77 & 105 & 63.73 \\
COD & $\mathrm{g} / \mathrm{L}$ & 50 & 147.5 & 500 & 132 \\
Total alkalinity & $\mathrm{mg} / \mathrm{L}$ & 3700 & 550 & 9000 & 450 \\
VFA (mg/L) & $\mathrm{mg} / \mathrm{L}$ & 13950 & 2475 & 5.3 & 1500 \\
pH & - & 7.1 & 4.5 & 4.3 \\
\hline
\end{tabular}

agricultural waste, municipal solid waste, and glucose, the organic fraction of municipal solid waste or food waste (FW) is getting more attraction due to higher content of volatile solids and organic matter [10-12]. The FW is abundantly available as in the year 2010, 352 Mt was produced in China, where the major contributors were restaurants and hotels as one-third of the ordered food ended in the dust bin $[13,14]$. The major components of FW were rice and noodle, as $40 \%$ of FW is consisted of rice waste (RW) and noodle waste (NW) [15].

During the biohydrogen production from FW and sludge, biohydrogen production rate, bacterial growth, microbial activities, and metabolic pathways are strongly affected by $\mathrm{pH}$, as the degradation of food waste occurs [16]. Volatile fatty acids (VFA) are also produced during this process, which lowers the $\mathrm{pH}$ of the medium, and if the $\mathrm{pH}$ is reduced to 4 , it may cease the biohydrogen production $[17,18]$. In such acidic conditions, ATP does not produce biohydrogen but maintains the neutrality among the cells [19]. On the other end, increasing the $\mathrm{pH}$ to specific level also increases the biohydrogen production due to an increase in bacteria growth but after that specific $\mathrm{pH}$, further increase in $\mathrm{pH}$ may decrease ATP level, which ultimately inhibits the bacterial growth [20]. Also, the methanogen activities possibly increase at higher $\mathrm{pH}$, which consumes the biohydrogen producers, and reduce the yield [21]. Initial $\mathrm{pH}$ of anaerobic reactor also affects the biohydrogen production process, so the initial $\mathrm{pH}$ of 7 is opted in most cases [11, 22, 23]. Shinya et al. [24] reported optimum $\mathrm{pH}$ range for biohydrogen production as 4.5 to 8.5 and further research made by Tawfik and El-Qelish [25] modified the $\mathrm{pH}$ range as 5 to 6.5 , which was further modified to 5-6, and the findings of Zhu et al. [11] changed this range to 5.5-6. Briefly, the optimum $\mathrm{pH}$ conditions vary with temperature, inoculum type, feed stock, and reactor type [26].

In various studies, a specific $\mathrm{pH}$ value was maintained for biohydrogen production. Okamoto et al. [27] maintained pH 7 and Fang kept $\mathrm{pH}$ at 4.5 during whole incubation. But maintaining $\mathrm{pH}$ at a specific value is not an easy task, whereas an average $\mathrm{pH}$ value can be easily maintained by automatic $\mathrm{pH}$ controller $[28,29]$. The specific range of $\mathrm{pH}$ can be maintained manually by monitoring the $\mathrm{pH}$ continuously with the help of $\mathrm{pH}$ electrode and then adjusting the $\mathrm{pH}$ to a desired value by using $\mathrm{HCl}$ or $\mathrm{KOH}$ [30]. Sometimes, continuous monitoring of $\mathrm{pH}$ is not feasible; therefore on the basis of experience and literature reviewed, many scientists maintained $\mathrm{pH}$ to a specific value after some interval, for example, after every twenty-four hours [18, 31]. In another approach, initial $\mathrm{pH}$ is maintained to such a value that, even after drop in $\mathrm{pH}$, the final $\mathrm{pH}$ at the end of incubation remained within the optimum $\mathrm{pH}$ range for biohydrogen production $[22,25]$. Sometimes, only maintaining initial $\mathrm{pH}$ is not enough, especially while working at low $\mathrm{pH}$ values of 5.5 or 4.5. In this situation, buffers or nutrients are added to maintain specific $\mathrm{pH}$ or to improve alkalinity that can slow down drop in $\mathrm{pH}[11,32]$.

Along with $\mathrm{pH}$, temperature is also an important environmental parameter which strongly affects the biohydrogen production. Most of the studies on biohydrogen production are conducted under mesophilic and thermophilic conditions [33]. A few studies were reported under psychrophilic conditions, where microbial electrolysis cells were developed for biohydrogen production, whereas no such a sophisticated technology is required for biohydrogen production under mesophilic as well as thermophilic temperature conditions [34].

The present study is designed in order to observe the impact of $\mathrm{pH}$ management interval on biohydrogen production under mesophilic thermophilic codigestion of food waste and its derivatives with sludge used as source of Clostridium mix consortia.

\section{Material and Methods}

2.1. Feedstock. Food waste was collected from Qīngzhēn dining at Engineering College, Nanjing Agricultural University, Nanjing. It was the food left on the plates after lunch/dinner consisting of rice, meat, tofu, egg, noodles bones, potato, and other vegetables. At first, bones and other foreign materials were removed followed by the separation of rice and noodles. These were ground in a meat grinder with equal proportion of water so that the resultant slurry could be used for hydrogen production [35]. The sludge was obtained from settling channel, which was sieved and washed to remove impurities and dirt [23]. Later on, the sludge was heated in an oven for 15 minutes at $100^{\circ} \mathrm{C}$, in order to deactivate methanogens [36]. Table 1 contained some important aspects of feedstock.

2.2. Experimental Design. FW, RW, and NW were mixed in equal proportion with sludge in six $550 \mathrm{~mL}$ digesters, two for 


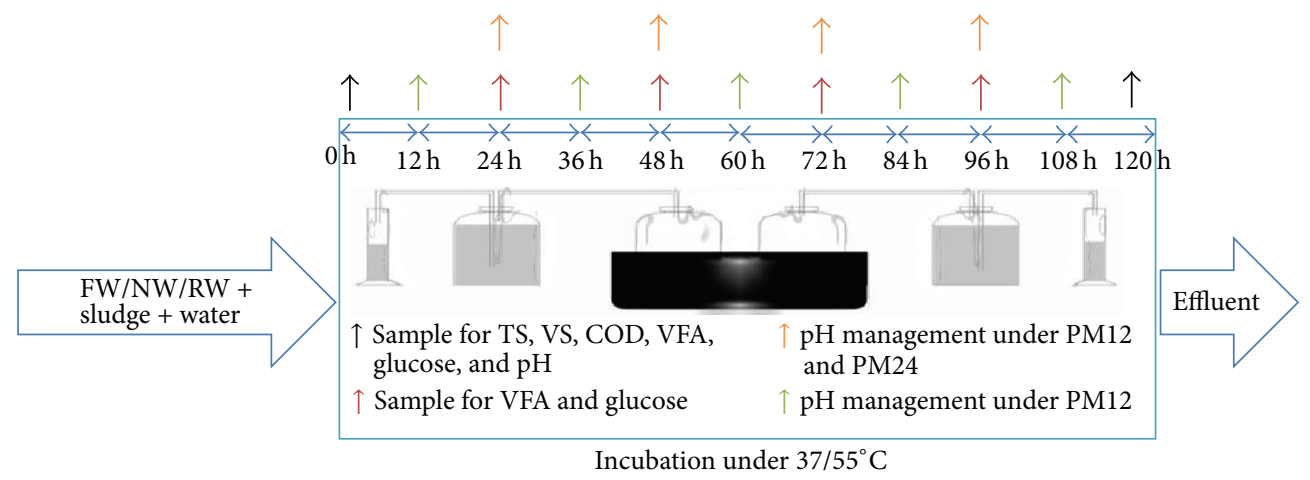

FIgURE 1: Schematic diagram for sampling and $\mathrm{pH}$ control.

each waste type. The working volume of each reactor was $400 \mathrm{~mL}$. Initial total solids (TS) were kept to $10 \%$ and $\mathrm{pH}$ was initially maintained at 7 for each reactor. These reactors were placed in two water baths: one at mesophilic temperature $\left(37 \pm 0.1^{\circ} \mathrm{C}\right)$ and the other at thermophilic temperature $\left(55 \pm 0.1^{\circ} \mathrm{C}\right)$. Two sets of experiments (in duplicate) were performed $[11,34]$. In the first set of experiments, $\mathrm{pH}$ was maintained to 7 after every 24 hours, and in second set of experiments, $\mathrm{pH}$ was maintained to 7 after every 12 hours. For ease of representation, 12-hour $\mathrm{pH}$ management was coded as PM12 and 24-hour pH management as PM24. The schematic diagram for sampling and $\mathrm{pH}$ control is shown in Figure 1.

2.3. Analytic Methods and Kinetic Modeling. The biohydrogen production volume was measured by connecting each reactor with a measuring bottle containing $3 \% \mathrm{NaOH}$ solution that could remove other gases and water vapors. The volume of $\mathrm{NaOH}$ displaced out was measured by measuring cylinder as a volume of biohydrogen produced in $\mathrm{mL}$ [37-39]. The total solids (TS), volatile solids (VS), chemical oxygen demand (COD), and volatile fatty acids (VFA) were measured according to standard methods [40]. The phenol sulfuric acid method was used to measure glucose content [41]. For TS, VS, and COD, samples were taken before and after incubation, whereas for VFA and glucose, samples were taken with glass syringe after every twenty-four hours [42]. For $\mathrm{pH}$ monitoring and control, $5 \mathrm{~mL}$ sample was taken and the $\mathrm{pH}$ was monitored with $\mathrm{pH}$ meter. The $\mathrm{pH}$ was adjusted to 7 by adding $3 \mathrm{M} \mathrm{NaOH}$ or $3 \mathrm{M} \mathrm{HCl}$ with a syringe [30].

2.4. Assay Methods. The kinetic modeling was done by a modified Gompertz equation that was used for cumulative biohydrogen measurement [43]

$$
H=P \exp \left\{-\exp \left[\frac{R_{m} e}{P}(\lambda-t)+1\right]\right\},
$$

where $H, t, P, R_{m}, \lambda$, and $e$ represent cumulative hydrogen production $(\mathrm{mL})$, incubation time $(\mathrm{h})$, hydrogen production potential, maximum hydrogen production rate $(\mathrm{mL} / \mathrm{h})$, lag phase duration $(\mathrm{h})$, and 2.71828 , respectively. The equation was solved by using Matlab (ver. 2010 a).

\section{Results and Discussion}

3.1. Biohydrogen Production. The biohydrogen production was modeled by using modified Gompertz equation and the results obtained were drawn in comparison with experimental results. It is clear form Figure 2 that the start of biohydrogen production was independent of $\mathrm{pH}$ management interval as both were under the same conditions during the first 12 hours of incubation. On the other end, the effect of increasing temperature varies as feedstock changes. The increase in temperature from $37^{\circ} \mathrm{C}$ to $55^{\circ} \mathrm{C}$ caused an early start of biohydrogen production in FW reactor whereas the same increase in temperature did not affect the initiation of biohydrogen production in case of NW rectors. The biohydrogen production in RW reactors was also not affected by the increase in temperature, but the production started after 12 hours of incubation as compared to NW where it started during 12 hours of incubation. The biohydrogen production was ceased in most of the reactors after 72 hours of incubation, which is in agreement with the previous studies $[32,34]$. The impact of $\mathrm{pH}$ management interval on biohydrogen production can be observed in Figure 3, where the differences in biohydrogen production under both $\mathrm{pH}$ managements were drawn on 12-hourly basis. In case of FW reactor, at $37^{\circ} \mathrm{C}, \mathrm{PM} 12$ was less dominant over PM24 till 48 hours of incubation, but after this time, PM24 remained dominant till 72 hours of incubation. Increasing the temperature from $37^{\circ} \mathrm{C}$ to $55^{\circ} \mathrm{C}$ changed the domination from 48 hours to 72 hours, but as a whole, PM12 remained dominant. When feedstock was changed from FW to NW, the change in domination was observed after 60 hours of incubation at $37^{\circ} \mathrm{C}$ with one exception that PM24 was dominated between 12 and 24 hours of incubation. On the other end, increase in temperature from $37^{\circ} \mathrm{C}$ to $55^{\circ} \mathrm{C}$ for $\mathrm{NW}$ reactor dominated the PM24 after 48 hours of incubation and as a whole there was little difference observed in both $\mathrm{pH}$ managements. The rice waste represented different situation where the PM12 was highly dominated between 60 and 84 hours of incubation at $37^{\circ} \mathrm{C}$ temperature conditions. When the temperature was increased to $55^{\circ} \mathrm{C}, \mathrm{PM} 12$ remained dominated except between 48 and 60 hours where PM24 dominated.

The kinetic parameters assessed on the basis of the modified Gompertz equation are listed in Table 2. For FW, 
TABLE 2: Kinetic parameters and biohydrogen yield.

\begin{tabular}{|c|c|c|c|c|c|c|c|c|}
\hline Waste type & $\begin{array}{c}\text { Temperature } \\
\left({ }^{\circ} \mathrm{C}\right) \\
\end{array}$ & $\begin{array}{c}\text { pH management interval } \\
(\mathrm{h})\end{array}$ & $\begin{array}{c}P \\
(\mathrm{~mL})\end{array}$ & $\begin{array}{c}R_{m} \\
(\mathrm{~mL} / \mathrm{h})\end{array}$ & $\begin{array}{c}\lambda \\
(\mathrm{h}) \\
\end{array}$ & $R^{2}$ & $\begin{array}{l}\text { Biohydrogen yield } \\
\mathrm{mL} / \mathrm{g} \mathrm{COD}_{\text {removed }}\end{array}$ & 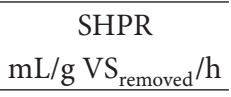 \\
\hline \multirow{4}{*}{ Food waste } & \multirow{2}{*}{37} & 12 & 534.9 & 15.36 & 22.34 & 0.9998 & 56.31 & 1.90 \\
\hline & & 24 & 490.1 & 13.34 & 24.1 & 0.9969 & 39.20 & 1.56 \\
\hline & \multirow{2}{*}{55} & 12 & 1076 & 19.79 & 12.45 & 0.9971 & 89.67 & 1.95 \\
\hline & & 24 & 981.2 & 10.09 & 3.22 & 0.9885 & 85.32 & 0.96 \\
\hline \multirow{4}{*}{ Noodle waste } & \multirow{2}{*}{37} & 12 & 2189 & 65.66 & 16.33 & 0.9935 & 145.93 & 3.47 \\
\hline & & 24 & 1193 & 43.08 & 9.32 & 0.991 & 91.77 & 2.31 \\
\hline & \multirow{2}{*}{55} & 12 & 1712 & 48.94 & 4.63 & 0.994 & 122.28 & 2.14 \\
\hline & & 24 & 1723 & 25.56 & 8.56 & 0.982 & 132.54 & 1.28 \\
\hline \multirow{4}{*}{ Rice waste } & \multirow{2}{*}{37} & 12 & 1529 & 34.49 & 37.73 & 0.9867 & 117.62 & 2.35 \\
\hline & & 24 & 876 & 23.62 & 31.31 & 0.9819 & 73 & 1.97 \\
\hline & \multirow{2}{*}{55} & 12 & 448.20 & 6.44 & 18.02 & 0.9779 & 44.82 & 0.67 \\
\hline & & 24 & 122.90 & 4.25 & 35.02 & 0.9897 & 15.36 & 0.53 \\
\hline
\end{tabular}

SHPR stands for specific biohydrogen production rate.

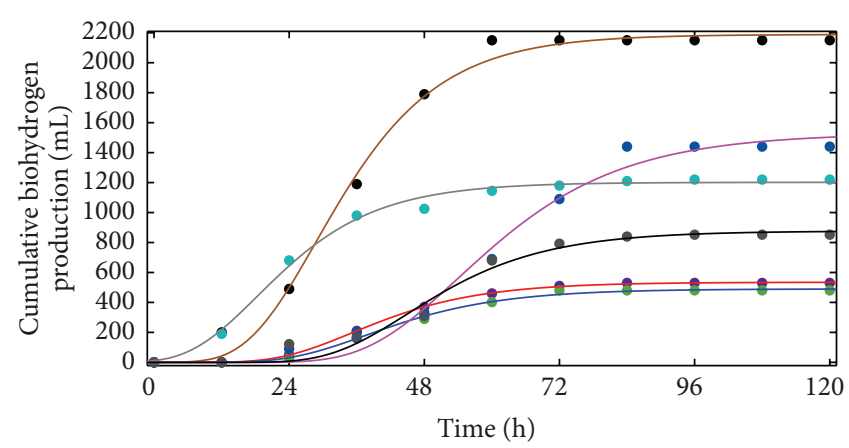

- Food waste, PM12

_ Food waste, PM12, $M$

- Food waste, PM24

— Food waste, PM24, $M$

- Noodle waste, PM12

— Noodle waste, PM12, $M$

(a)

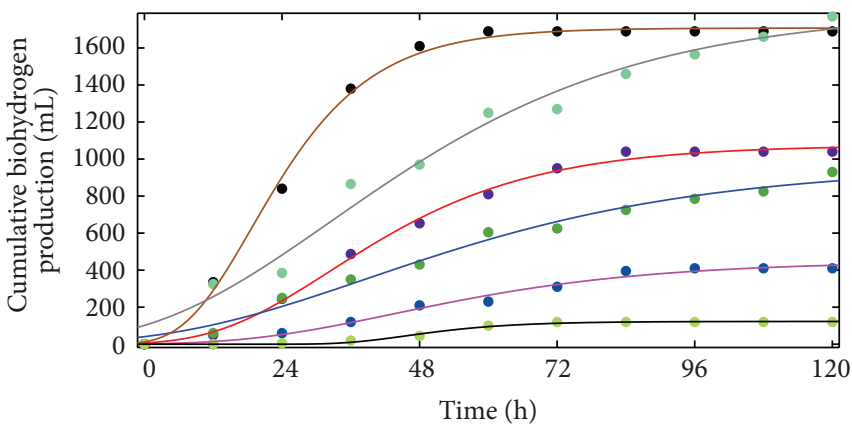

- Food waste, $12 \mathrm{~h}$ Noodle waste, $24 \mathrm{~h}$

— Food waste, $12 \mathrm{~h}, M \quad$ Noodle waste, $24 \mathrm{~h}, \mathrm{M}$

- Food waste, $24 \mathrm{~h}$ - Rice waste, $12 \mathrm{~h}$

- Food waste, $24 \mathrm{~h}, M \quad$ Rice waste, $12 \mathrm{~h}, M$

- Noodle waste, $12 \mathrm{~h}$ - Rice waste, $24 \mathrm{~h}$

- Noodle waste, $12 \mathrm{~h}, M$ Rice waste, $24 \mathrm{~h}, M$

(b)

FIGURE 2: Biohydrogen production under $12 \mathrm{~h}$ and $24 \mathrm{~h}$ management interval. (a) $37^{\circ} \mathrm{C}$; (b) $55^{\circ} \mathrm{C} . M$ modeled curve on the basis of modified Gompertz equation.

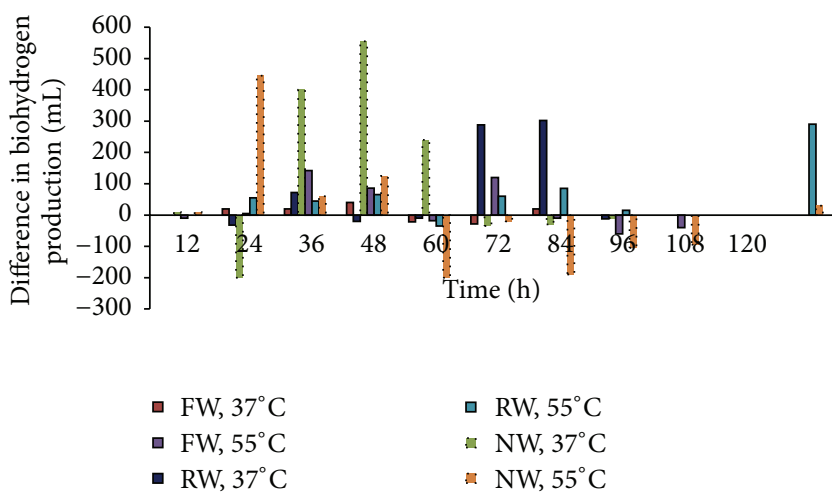

Figure 3: Comparison of biohydrogen production under PM12 over PM24. the highest value of $R_{m}$ was $19.76 \mathrm{~mL} / \mathrm{h}$ observed at $55^{\circ} \mathrm{C}$, PM12, and produced cumulative biohydrogen of $1076 \mathrm{~mL}$. In case of NW, the mesophilic value of $R_{m}$ was $65.66 \mathrm{~mL} / \mathrm{h}$ at PM12, which is much higher than $43.08 \mathrm{~mL} / \mathrm{h}$ observed at $\mathrm{PM} 24$. The increase in $\mathrm{pH}$ management duration and temperature form $37^{\circ} \mathrm{C}$ to $55^{\circ} \mathrm{C}$ decreased the value of $R_{m}$ for RW that can be observed in Table 2. On the whole, an increase in $\mathrm{pH}$ management time decreased the cumulative biohydrogen production for all waste types. The increase in temperature from $37^{\circ} \mathrm{C}$ to $55^{\circ} \mathrm{C}$ decreased $R_{m}$ for $\mathrm{NW}$ and RW, which ultimately reduced the biohydrogen production [18]. An increase in temperature increased the biohydrogen production for FW, although the thermophilic $R_{m}$ under PM24 was smaller than the mesophilic $R_{m}$ under PM24. It was due to lag phase duration that was small under 


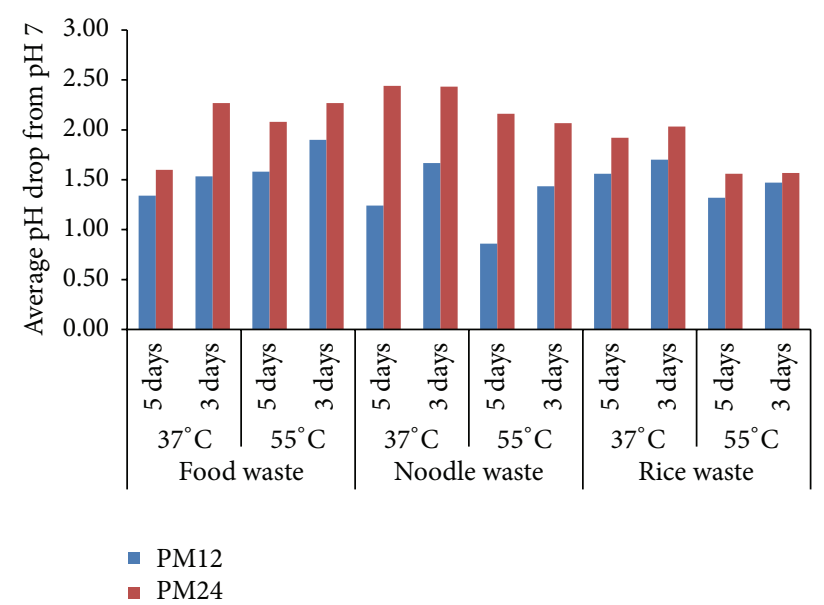

Figure 4: Drop in pH during PM12 and PM24.

thermophilic condition as compared to mesophilic conditions and also due to longer production time that can be observed in Figure 2 and Table 2.

3.2. Drop in $p H$. The production of biohydrogen occurred in acidification phase, which decreased the $\mathrm{pH}$ of the reactor [26], as most of the hydrogen production was observed during 72 hours of incubation after which the drop in $\mathrm{pH}$ was reduced (Figure 4). The average drop in $\mathrm{pH}$ during 5 days was lower than that observed during first 3 days, meaning thereby that the intensity of drop in $\mathrm{pH}$ reduced during last two days of incubation. The reduction in biohydrogen production and decrease in intensity of drop in $\mathrm{pH}$ indicated the possibility of activation of methanogenic bacteria, which were deactivated initially by heat treatment $[44,45]$. It is obvious that the drop in $\mathrm{pH}$ increases when $\mathrm{pH}$ management interval increases; still the drop in $\mathrm{pH}$ difference for PM24 was not so higher than PM12 specifically during 72 hours of incubation. As compared to other reactors, NW rector has higher average $\mathrm{pH}$ drop during 5 days under PM12 and PM24. It was because of reduction in drop of $\mathrm{pH}$, especially after 72 hours of incubation under PM12 that ultimately caused higher difference between the drop of $\mathrm{pH}$ under PM12 and PM24. The drop in $\mathrm{pH}$ decreased with an increase in temperature for RW and NW. In the reactors, which attained higher biohydrogen production such as thermophilic FW, mesophilic NW, and mesophilic RW, average drop in $\mathrm{pH}$ was from 7 to 5.1, 5.3, and 5.3, respectively [25].

3.3. Biohydrogen Yield. Biohydrogen yield was calculated by dividing the cumulative biohydrogen production with $\mathrm{COD}_{\text {removed }}$ and the highest biohydrogen yield of $145.93 \mathrm{~mL} / \mathrm{g}$ $\mathrm{COD}_{\text {removed }}$ was obtained by $\mathrm{NW}$ reactor at $37^{\circ} \mathrm{C}$ under PM12. The biohydrogen yields of all tested wastes in the present study are listed in Table 2, which are in agreement with the previous studies, although the $\mathrm{pH}$ management method used was different $[25,46]$. On the other end, Wongthanate and Chinnacotpong [47] obtained biohydrogen yield of $44.83 \mathrm{~mL} / \mathrm{g}$ COD under no $\mathrm{pH}$ control conditions which was $89.67 \mathrm{~mL} / \mathrm{g}$ COD obtained in the present study from FW under PM12, indicating the positive impact of $\mathrm{pH}$ management.

The increase in $\mathrm{pH}$ management interval decreased the biohydrogen yield for FW which was higher under mesophilic conditions as compared to thermophilic conditions, that is, $60 \%$ and $6.42 \%$ decrease in biohydrogen yield at $37^{\circ} \mathrm{C}$ and $55^{\circ} \mathrm{C}$, respectively. At the same time, increase in $\mathrm{pH}$ management interval also increased the average drop in $\mathrm{pH}$ from 5.1 to 4.7 under thermophilic conditions, whereas the drop in biohydrogen yield due to such $\mathrm{pH}$ shift was not so high under the same temperature conditions. So the optimum $\mathrm{pH}$ range of biohydrogen production from $\mathrm{FW}$ under thermophilic conditions could be considered as 7 to 4.7. On the other end, the increase in temperature from $37^{\circ} \mathrm{C}$ to $55^{\circ} \mathrm{C}$ increased biohydrogen yield by $66.67 \%$ and $142 \%$ under PM12 and PM24, respectively [30].

For NW, changing from PM12 to PM24 caused a 57.61\% decrease in biohydrogen yield under mesophilic conditions. But the situation was different under thermophilic conditions where $10.36 \%$ increase in biohydrogen yield was observed by changing from PM12 to PM24. During biohydrogen production at $55^{\circ} \mathrm{C}$, the average drop in $\mathrm{pH}$ from 7 was 5.6 and 4.9 under PM12 and PM24, respectively. As the thermophilic biohydrogen yield was higher than the mesophilic biohydrogen yield under $\mathrm{PM} 24$, so the optimum $\mathrm{pH}$ range for biohydrogen production from NW was observed between 7 and 4.9.

In case of RW, the biohydrogen yield decreased from PM12 to PM24, that is, $61.67 \%$ and $135.48 \%$ decrease in biohydrogen yield at $37^{\circ} \mathrm{C}$ and $55^{\circ} \mathrm{C}$, respectively. Similarly, an increase in temperature from $37^{\circ} \mathrm{C}$ to $55^{\circ} \mathrm{C}$ decreased biohydrogen yield by $62.46 \%$ and $74.23 \%$ under PM12 and PM24, respectively [18]. The highest experimental biohydrogen yield of $117.61 \mathrm{~mL} / \mathrm{g} \mathrm{COD}$ removed from RW was observed under mesophilic conditions with PM12. Keeping in view the average $\mathrm{pH}$ drop, optimum $\mathrm{pH}$ range of biohydrogen production from RW was observed between 7 and 5.3.

3.4. Glucose Consumption. The mix consortia of Clostridium metabolize glucose into pyruvate that is further oxidized to ferredoxin, which is ultimately converted to hydrogen and volatile fatty acids $[48,49]$. Due to such metabolism, there was a sudden drop in glucose concentration with little biohydrogen production during the first $24 \mathrm{~h}$ of incubation in all reactors that was also observed in previous studies $[32,50]$. As it is already discussed that most of the biohydrogen was produced during $72 \mathrm{~h}$ of incubation and during the same interval, as a whole, average glucose consumption was $80 \%$ (Figure 5) that is in agreement with the previous studies $[32,39]$.

The increase in temperature from mesophilic to thermophilic and increase in $\mathrm{pH}$ management interval increased the glucose consumption for FW and NW as shown in Figures 5(a) and 5(b). Keeping in view the above fact, FW and NW thermophilic reactors under PM24 have higher glucose consumption as compared to other reactors as biohydrogen production was not fully ceased in these reactors till the end 


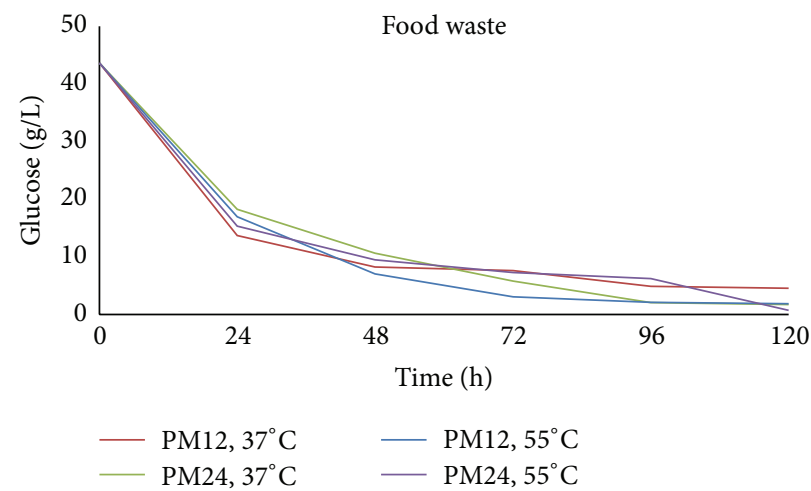

(a)

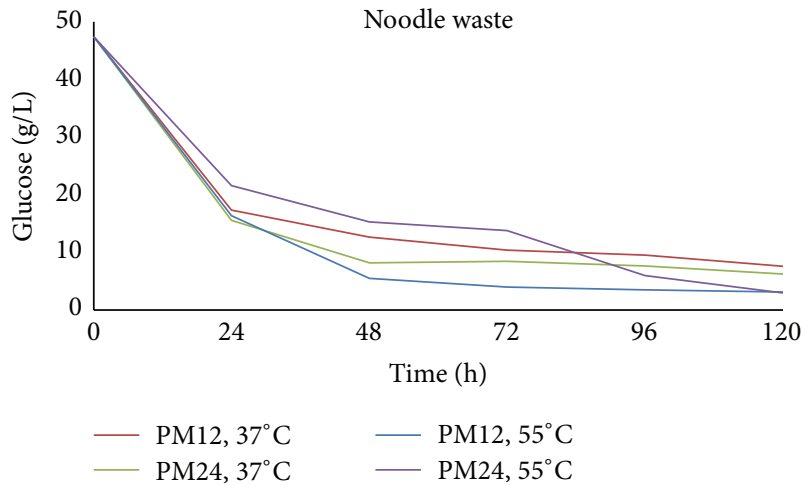

(b)

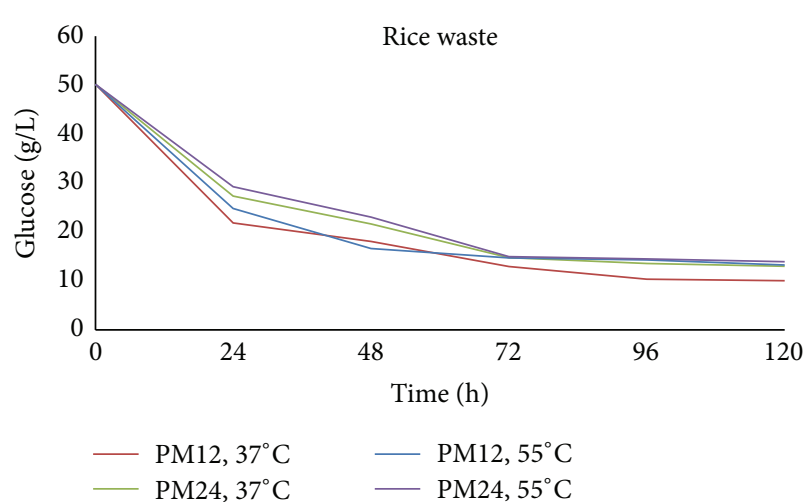

(c)

FIGURE 5: Glucose consumption during incubation.

of incubation (Figure 2(b)). As the gas production was continued in these reactors, so the glucose consumption also remained higher as compared to other reactors, especially after 72 hours of incubation (Figures 5(a) and 5(b)). On the other end, RW reactors represented opposite trends as observed for FW and NW with respect to temperature and $\mathrm{pH}$ management (Figure 5(c)). The highest consumption of glucose for RW was observed in mesophilic reactor under PM12 having higher biohydrogen production potential as compared to other RW reactors.

3.5. VFA Production. The VFA production represented an increasing trend with incubation time as observed in studies made by other researchers $[18,22]$. The overall increase in VFA was also observed when $\mathrm{pH}$ management was changed from PM12 to PM24 as shown in Figure 6. The mesophilic FW and NW reactors under PM24 represented a higher VFA concentration at the end of incubation as compared to other reactors. That might be associated with the conversion of glucose into VFA instead of biohydrogen, especially after 60 hours of incubation (Figure 6(a) and 6(b)). On the other end, an increase in temperature from $37^{\circ} \mathrm{C}$ to $55^{\circ} \mathrm{C}$ increased the VFA for FW under PM12, but it decreased the VFA for all other reactors (Figure 6). Such a variable impact of temperature on VFA is due to variation in test conditions like different feedstock and $\mathrm{pH}$ environment and so forth, as observed in previous studies [30,51].
There was a sudden increase in VFA concentration between $24 \mathrm{~h}$ and $48 \mathrm{~h}$ of incubation in FW reactor under PM24, which considerably reduced the biohydrogen production as compared to the FW reactor under PM12 (Figures 2 and 6(a)), whereas such increase in VFA was observed in the $\mathrm{NW}$ and RW reactors between $48 \mathrm{~h}$ and $72 \mathrm{~h}$ of incubation under PM24 but did not considerably affect biohydrogen production in RW reactors, as a similar increase in VFA concentration was also observed under PM12 (Figure 6(c)).

After $72 \mathrm{~h}$ of incubation, the increase in VFA under PM24 was much higher than PM12 in all reactors under mesophilic as well as thermophilic conditions. The NW reactors have the highest concentration of VFA as observed previously [39]. Overall, it was observed that PM12 not only controls the production of VFA but also increases the biohydrogen production potential of waste types tested in present study.

\section{Conclusion}

The effect of $\mathrm{pH}$ management interval on biohydrogen production from the organic fraction of municipal solid waste was studied under mesophilic and thermophilic conditions. Managing the $\mathrm{pH}$ after specific intervals was found to be a practical approach to enhancing biohydrogen production. The biohydrogen yields of $145.93 \mathrm{~mL} / \mathrm{g} \mathrm{COD}_{\text {removed }}$, $89.67 \mathrm{~mL} / \mathrm{g} \mathrm{COD}_{\text {removed }}$, and $117.61 \mathrm{~mL} / \mathrm{g} \mathrm{COD}_{\text {removed }}$ were obtained for FW, NW, and RW, respectively, under PM12 


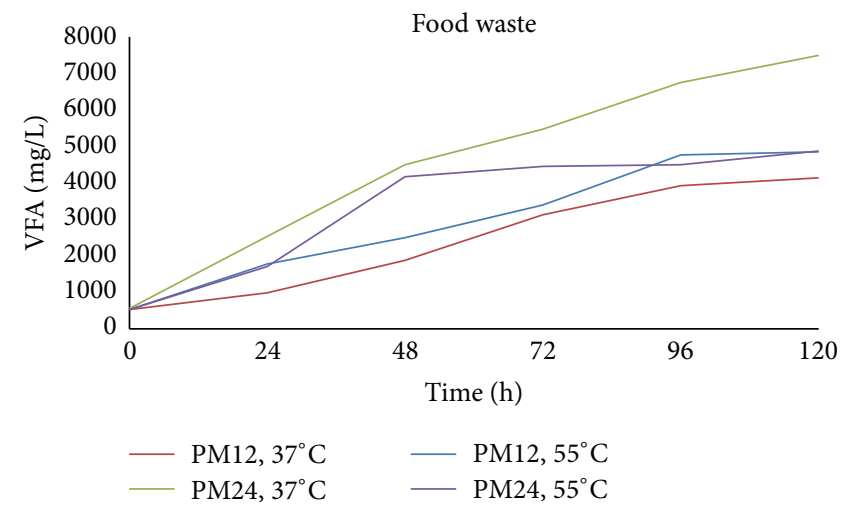

(a)

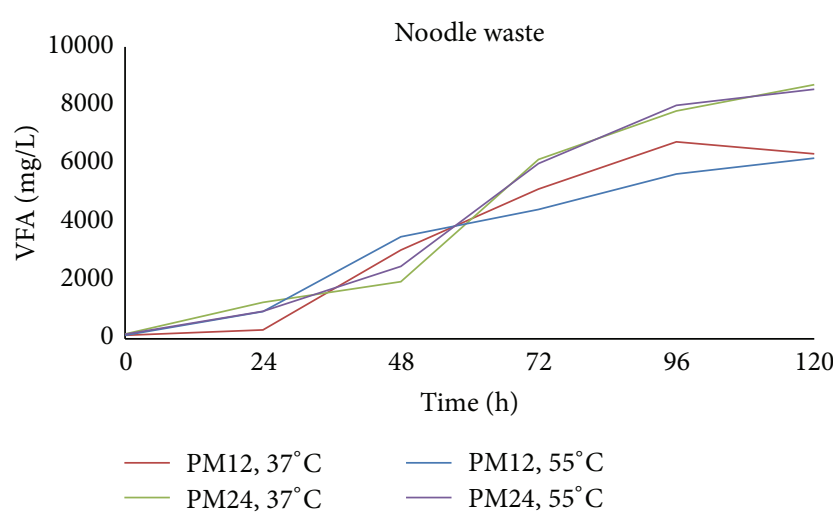

(b)

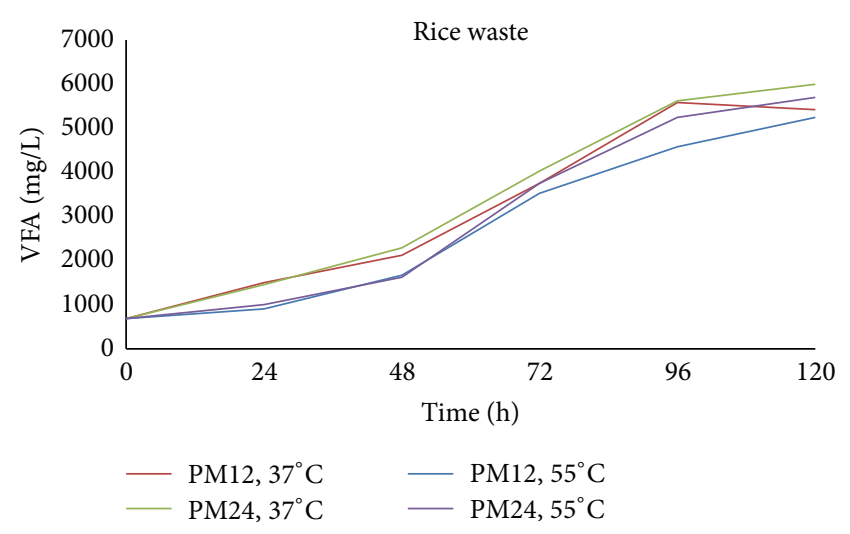

(c)

FIGURE 6: VFA production during incubation.

which were higher than those obtained under PM24. Increasing in temperature from $37^{\circ} \mathrm{C}$ to $55^{\circ} \mathrm{C}$ was observed to be an effective mean to enhance the biohydrogen yield for FW only. PM12 was more effective than PM24 to control the production of VFA. The results obtained in this study are useful for designing $\mathrm{pH}$ operating conditions for anaerobic reactor in order to produce biohydrogen.

\section{Conflict of Interests}

The authors declare that there is no conflict of interests regarding the publication of this paper.

\section{Authors' Contribution}

Chaudhry Arslan and Asma Sattar contributed equally to this work.

\section{Acknowledgments}

The authors thank Professor Chen Kunji for providing lab facilities; Fang Huimin, Huang Yu Ping, and Kang Jiao Bin for their help during lab work; Dr. Farman Ali Chandio and Dr. Fiaz Ahmad for helpful discussion and critical review. The authors extend their thanks to Higher Education Commission, Pakistan, China Scholarship Council, and the College of Engineering, Nanjing Agricultural University, Nanjing, for supporting and providing research facilities for this study.

\section{References}

[1] P. L. McCarty, "One hundred years of anaerobic treatment," in Anaerobic Digestion, pp. 3-22, 1981.

[2] I. K. Kapdan and F. Kargi, "Bio-hydrogen production from waste materials," Enzyme and Microbial Technology, vol. 38, no. 5, pp. 569-582, 2006.

[3] H. Nazlina, A. N. Aini, F. Ismail, M. Yusof, and M. Hassan, "Effect of different temperature, initial $\mathrm{pH}$ and substrate composition on biohydrogen production from food waste in batch fermentation," Asian Journal of Biotechnology, vol. 1, no. 2, pp. 42-50, 2009.

[4] G. Antonopoulou, H. N. Gavala, I. V. Skiadas, and G. Lyberatos, "Influence of $\mathrm{pH}$ on fermentative hydrogen production from sweet sorghum extract," International Journal of Hydrogen Energy, vol. 35, no. 5, pp. 1921-1928, 2010.

[5] J. X. W. Hay, T. Y. Wu, J. C. Juan, and J. M. Jahim, "Biohydrogen production through photo fermentation or dark fermentation using waste as a substrate: overview, economics, and future prospects of hydrogen usage," Biofuels, Bioproducts and Biorefining, vol. 7, no. 3, pp. 334-352, 2013.

[6] K. Brenner, L. You, and F. H. Arnold, "Engineering microbial consortia: a new frontier in synthetic biology," Trends in Biotechnology, vol. 26, no. 9, pp. 483-489, 2008. 
[7] H. Y. Choi, S. Y. Park, Y. Kim et al., "The epidemiology and economic burden of Clostridium difficile infection in Korea," BioMed Research International, vol. 2015, Article ID 510386, 8 pages, 2015.

[8] T. Tommasi, G. Sassi, and B. Ruggeri, "Acid pre-treatment of sewage anaerobic sludge to increase hydrogen producing bacteria HPB: effectiveness and reproducibility," Water Science and Technology, vol. 58, no. 8, pp. 1623-1628, 2008.

[9] Y.-T. Fan, Y.-H. Zhang, S.-F. Zhang, H.-W. Hou, and B.-Z. Ren, "Efficient conversion of wheat straw wastes into biohydrogen gas by cow dung compost," Bioresource Technology, vol. 97, no. 3, pp. 500-505, 2006.

[10] R. Zhang, H. M. El-Mashad, K. Hartman et al., "Characterization of food waste as feedstock for anaerobic digestion," Bioresource Technology, vol. 98, no. 4, pp. 929-935, 2007.

[11] H. Zhu, W. Parker, R. Basnar et al., "Biohydrogen production by anaerobic co-digestion of municipal food waste and sewage sludges," International Journal of Hydrogen Energy, vol. 33, no. 14, pp. 3651-3659, 2008.

[12] D. J. Lee, S. Y. Lee, J. S. Bae et al., "Effect of volatile fatty acid concentration on anaerobic degradation rate from field anaerobic digestion facilities treating food waste leachate in South Korea," Journal of Chemistry, vol. 2015, Article ID 640717, 9 pages, 2015.

[13] J. Tai, W. Zhang, Y. Che, and D. Feng, "Municipal solid waste source-separated collection in China: a comparative analysis," Waste Management, vol. 31, no. 8, pp. 1673-1682, 2011.

[14] L. Wang, S. Cheng, Q. Li, and X. Zengrang, “Tourist dining behavior in Lhasa city," Resources Science, vol. 35, no. 4, pp. 848857, 2013 (Chinese).

[15] X. Shiwei, "Analysis of China food consumption and waste," Food and Nutrition in China, vol. 11, no. 74, pp. 4-8, 2005.

[16] D.-Y. Cheong and C. L. Hansen, "Feasibility of hydrogen production in thermophilic mixed fermentation by natural anaerobes," Bioresource Technology, vol. 98, no. 11, pp. 22292239, 2007.

[17] M. Morimoto, M. Atsuko, A. A. Y. Atif et al., "Biological production of hydrogen from glucose by natural anaerobic microflora," International Journal of Hydrogen Energy, vol. 29, no. 7, pp. 709-713, 2004.

[18] H. H. P. Fang, C. Li, and T. Zhang, "Acidophilic biohydrogen production from rice slurry," International Journal of Hydrogen Energy, vol. 31, no. 6, pp. 683-692, 2006.

[19] M.-L. Chong, R. A. Rahim, Y. Shirai, and M. A. Hassan, "Biohydrogen production by Clostridium butyricum EB6 from palm oil mill effluent," International Journal of Hydrogen Energy, vol. 34, no. 2, pp. 764-771, 2009.

[20] G. Wang, Y. Mu, and H.-Q. Yu, "Response surface analysis to evaluate the influence of $\mathrm{pH}$, temperature and substrate concentration on the acidogenesis of sucrose-rich wastewater," Biochemical Engineering Journal, vol. 23, no. 2, pp. 175-184, 2005.

[21] I. Valdez-Vazquez and H. M. Poggi-Varaldo, "Hydrogen production by fermentative consortia," Renewable and Sustainable Energy Reviews, vol. 13, no. 5, pp. 1000-1013, 2009.

[22] Y. Lin, S. Wu, and D. Wang, "Hydrogen-methane production from pulp \& paper sludge and food waste by mesophilicthermophilic anaerobic co-digestion," International Journal of Hydrogen Energy, vol. 38, no. 35, pp. 15055-15062, 2013.

[23] C. Nathao, U. Sirisukpoka, and N. Pisutpaisal, "Production of hydrogen and methane by one and two stage fermentation of food waste," International Journal of Hydrogen Energy, vol. 38, no. 35, pp. 15764-15769, 2013.

[24] M. Shinya, O. Mizuno, K. Suzuki, J. Yaguchi, and T. E. Noike, "Effect of $\mathrm{pH}$ on hydrogen production from noodle manufacturing wastewater," Environmental Engineering Research, vol. 37, pp. 97-106, 2000 (Japanese).

[25] A. Tawfik and M. El-Qelish, "Key factors affecting on biohydrogen production from co-digestion of organic fraction of municipal solid waste and kitchen wastewater," Bioresource Technology, vol. 168, pp. 106-111, 2014.

[26] J. Wang and W. Wan, "Factors influencing fermentative hydrogen production: a review," International Journal of Hydrogen Energy, vol. 34, no. 2, pp. 799-811, 2009.

[27] M. Okamoto, T. Miyahara, O. Mizuno, and T. Noike, "Biological hydrogen potential of materials characteristic of the organic fraction of municipal solid wastes," Water Science and Technology, vol. 41, no. 3, pp. 25-32, 2000.

[28] N. H. M. Yasin, N. A. Rahman, H. C. Man, M. Z. Mohd Yusoff, and M. A. Hassan, "Microbial characterization of hydrogenproducing bacteria in fermented food waste at different $\mathrm{pH}$ values," International Journal of Hydrogen Energy, vol. 36, no. 16, pp. 9571-9580, 2011.

[29] C.-F. Chu, Y.-Y. Li, K.-Q. Xu, Y. Ebie, Y. Inamori, and H.-N. Kong, "A pH- and temperature-phased two-stage process for hydrogen and methane production from food waste," International Journal of Hydrogen Energy, vol. 33, no. 18, pp. 4739-4746, 2008.

[30] H.-S. Shin, J.-H. Youn, and S.-H. Kim, "Hydrogen production from food waste in anaerobic mesophilic and thermophilic acidogenesis," International Journal of Hydrogen Energy, vol. 29, no. 13, pp. 1355-1363, 2004.

[31] S.-H. Kim, S.-K. Han, and H.-S. Shin, "Optimization of continuous hydrogen fermentation of food waste as a function of solids retention time independent of hydraulic retention time," Process Biochemistry, vol. 43, no. 2, pp. 213-218, 2008.

[32] A. Marone, G. Izzo, L. Mentuccia et al., "Vegetable waste as substrate and source of suitable microflora for bio-hydrogen production," Renewable Energy, vol. 68, pp. 6-13, 2014.

[33] P. Mohammadi, S. Ibrahim, M. S. M. Annuar, S. Ghafari, S. Vikineswary, and A. A. Zinatizadeh, "Influences of environmental and operational factors on dark fermentative hydrogen production: a review," CLEAN-Soil, Air, Water, vol. 40, no. 11, pp. 1297-1305, 2012.

[34] L. Dong, Y. Zhenhong, S. Yongming, K. Xiaoying, and Z. Yu, "Hydrogen production characteristics of the organic fraction of municipal solid wastes by anaerobic mixed culture fermentation," International Journal of Hydrogen Energy, vol. 34, no. 2, pp. 812-820, 2009.

[35] A. Reungsang, C. Sreela-Or, and P. Plangklang, "Non-sterile bio-hydrogen fermentation from food waste in a continuous stirred tank reactor (CSTR): performance and population analysis," International Journal of Hydrogen Energy, vol. 38, no. 35, pp. 15630-15637, 2013.

[36] C. Li and H. H. P. Fang, "Fermentative hydrogen production from wastewater and solid wastes by mixed cultures," Critical Reviews in Environmental Science and Technology, vol. 37, no. 1, pp. 1-39, 2007.

[37] Y. Lin, J. Liang, S. Wu, and B. Wang, "Was pretreatment beneficial for more biogas in any process? Chemical pretreatment effect on hydrogen-methane co-production in a two-stage process," Journal of Industrial and Engineering Chemistry, vol. 19, no. 1, pp. 316-321, 2013. 
[38] P. Saraphirom and A. Reungsang, "Optimization of biohydrogen production from sweet sorghum syrup using statistical methods," International Journal of Hydrogen Energy, vol. 35, no. 24, pp. 13435-13444, 2010.

[39] C. Arslan, A. Sattar, C. Ji, S. Sattar, K. Yousaf, and S. Hashim, "Optimizing the impact of temperature on bio-hydrogen production from food waste and its derivatives under no $\mathrm{pH}$ control using statistical modelling," Biogeosciences, vol. 12, no. 21, pp. 6503-6514, 2015.

[40] APHA, Standard Methods for the Examination of Water and Wastewater, American Public Health Association, Washington, DC, USA, 25th edition, 2005.

[41] J.-J. Lay, K.-S. Fan, J. Chang, and C.-H. Ku, "Influence of chemical nature of organic wastes on their conversion to hydrogen by heat-shock digested sludge," International Journal of Hydrogen Energy, vol. 28, no. 12, pp. 1361-1367, 2003.

[42] C. Sreela-Or, T. Imai, P. Plangklang, and A. Reungsang, "Optimization of key factors affecting hydrogen production from food waste by anaerobic mixed cultures," International Journal of Hydrogen Energy, vol. 36, no. 21, pp. 14120-14133, 2011.

[43] C.-C. Chen, C.-Y. Lin, and M.-C. Lin, "Acid-base enrichment enhances anaerobic hydrogen production process," Applied Microbiology and Biotechnology, vol. 58, no. 2, pp. 224-228, 2002.

[44] C. Ramos, G. Buitrón, I. Moreno-Andrade, and R. Chamy, "Effect of the initial total solids concentration and initial $\mathrm{pH}$ on the bio-hydrogen production from cafeteria food waste," International Journal of Hydrogen Energy, vol. 37, no. 18, pp. 13288-13295, 2012.

[45] B. Schiel-Bengelsdorf and P. Dürre, "Pathway engineering and synthetic biology using acetogens," FEBS Letters, vol. 586, no. 15, pp. 2191-2198, 2012.

[46] D.-Y. Cheong, C. L. Hansen, and D. K. Stevens, "Production of bio-hydrogen by mesophilic anaerobic fermentation in an acidphase sequencing batch reactor," Biotechnology and Bioengineering, vol. 96, no. 3, pp. 421-432, 2007.

[47] J. Wongthanate and K. Chinnacotpong, "Optimal conditions for biological hydrogen production from food waste," Environmental Engineering Research, vol. 20, no. 2, pp. 121-125, 2015.

[48] P. C. Hallenbeck and J. R. Benemann, "Biological hydrogen production; fundamentals and limiting processes," International Journal of Hydrogen Energy, vol. 27, no. 11-12, pp. 1185-1193, 2002.

[49] C. Schröder, M. Selig, and P. Schönheit, "Glucose fermentation to acetate, $\mathrm{CO}_{2}$ and $\mathrm{H}_{2}$ in the anaerobic hyperthermophilic eubacterium Thermotoga maritima: involvement of the Embden-Meyerhof pathway," Archives of Microbiology, vol. 161, no. 6, pp. 460-470, 1994.

[50] P. Abdeshahian, N. K. N. Al-Shorgani, N. K. M. Salih et al., "The production of biohydrogen by a novel strain Clostridium sp. YM1 in dark fermentation process," International Journal of Hydrogen Energy, vol. 39, no. 24, pp. 12524-12531, 2014.

[51] S. I. Gadow, Y.-Y. Li, and Y. Liu, "Effect of temperature on continuous hydrogen production of cellulose," International Journal of Hydrogen Energy, vol. 37, no. 20, pp. 15465-15472, 2012. 

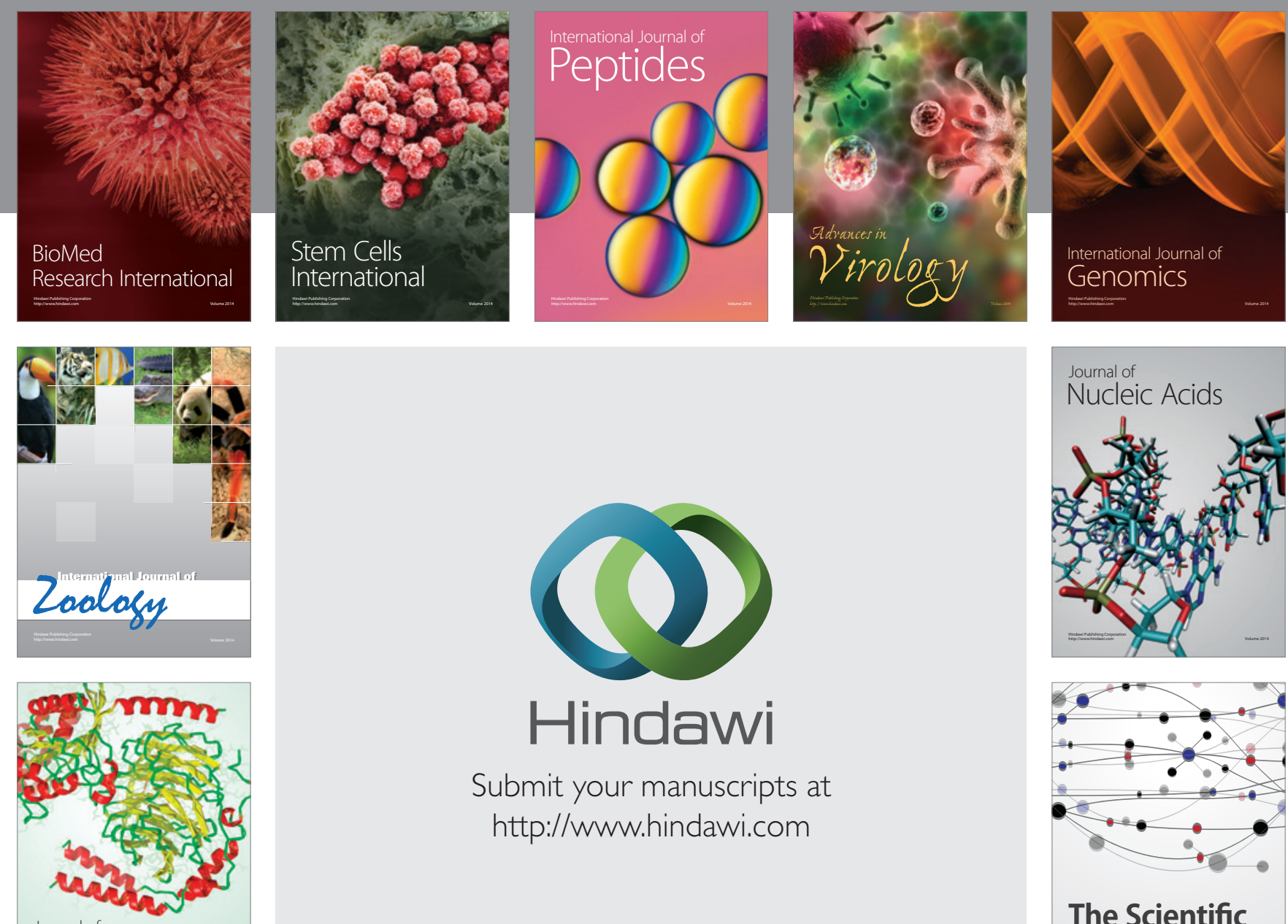

Submit your manuscripts at

http://www.hindawi.com

Journal of
Signal Transduction
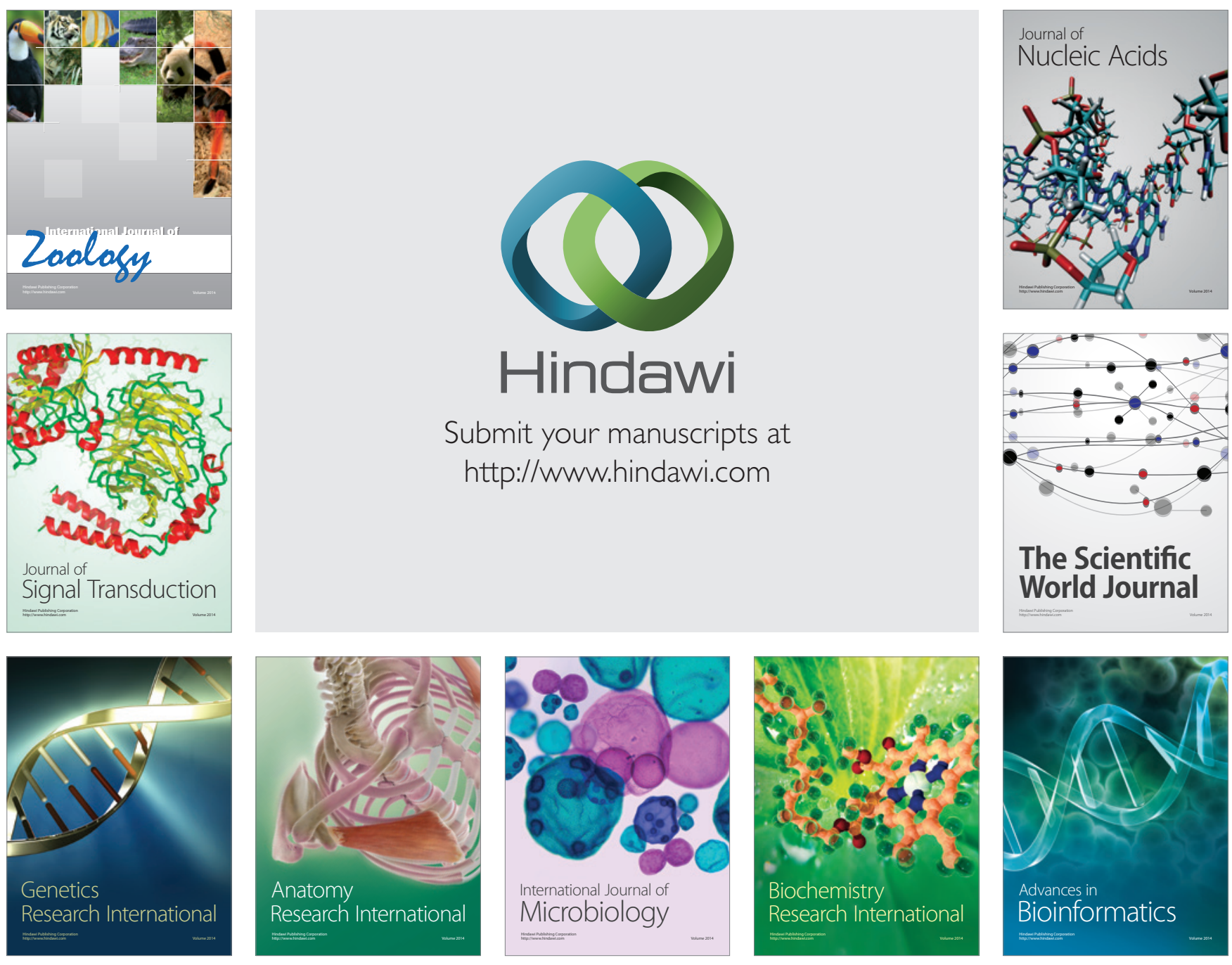

The Scientific World Journal
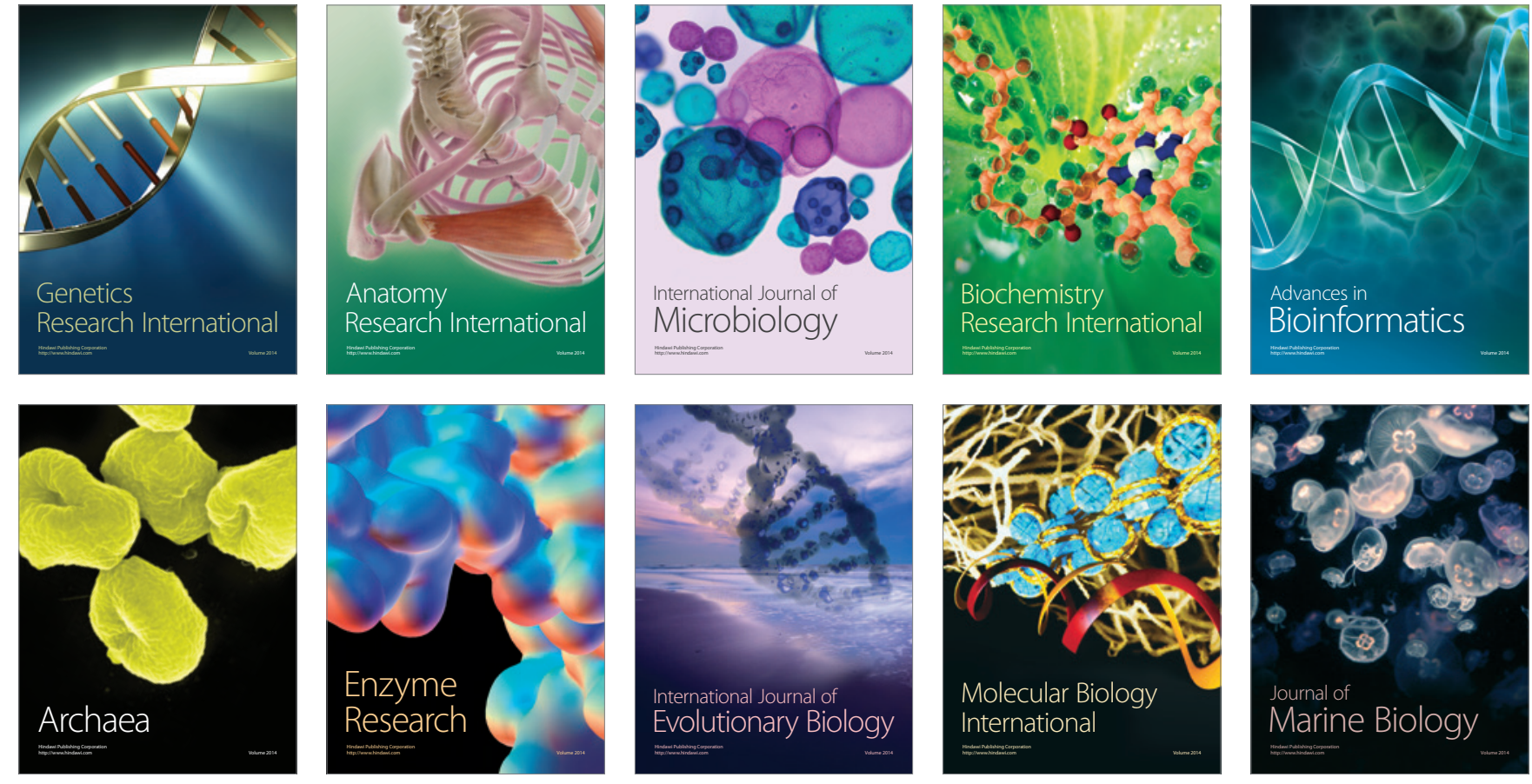